\title{
The model of cooperation with employers as the support measure for the development of entrepreneurial university potential
}

\author{
Aleksandra Kulpa-Puczyńska \\ Cardinal Stefan Wyszyński University in Warsaw
}

\begin{abstract}
Engaging the scientific sector into the development of economy, especially the regional one, influences the image of a modern higher education facility (creative and open towards the surrounding environment), whose traditional functions have been expanded by striving towards innovativeness and entrepreneurship. This paper attempts to contribute to the discussion of practitioners (which is held also in Poland) about the current condition and perspectives for the evolution of entrepreneurship at higher education facilities. The purpose of this elaboration is to present a particular model of cooperation with employers - a solution that has been introduced and is continuously being developed (assessed, analyzed) by the Cardinal Stefan Wyszyński University (UKSW) in Warsaw - and calling attention to additional opportunities for the development of entrepreneurial potential on the example of one of its faculties. The analysis of the given problem leads, among others, to the following conclusions: in order to achieve effective functioning of the described model it is necessary that the project is coordinated internally (at the level of a given department), it is also important to act systematically (and to initiate new actions determined by current needs of the labour market) and according to the academic policy of entrepreneurship and innovativeness.
\end{abstract}

Keywords: higher education facility; employers; model of cooperation; academic entrepreneurship

\section{Introduction - entrepreneurial nature of a modern higher education facility}

Higher education facilities have recently devoted much attention to spreading information about their scientific achievements and conducting an academic policy of commercialization. The "new" role of this education sector is accompanied by the Triple Helix model, which sets out the dynamics of university-industry-government relations. The model is based on the premise that the above-mentioned areas overlap and are increasingly dependent on one another. Moreover, each area plays roles that had earlier been assigned to another sector, reflecting a new emphasis on their relationships (Leydesdorff \& Etzkowitz, 1998). Thus, universities have begun to display a more entrepreneurial mindset (they are a place where new businesses start and local communities are mobilized to become active), companies participate in academic projects and local governments set up business incubators. Furthermore, the mutual overlapping of roles leads to the emergence of bridge institutions that operate within these three areas (Gunasekara, 2006).

The influence of higher education on economic growth is also a subject of the engaged university concept, which focuses on the development of education facilities and their potential of adapting to regional needs (Goldstein, 2010). By undertaking a variety of actions, a university does not strive towards replacing companies or governmental institutions but constitutes an important initiator of cooperation between local institutions (OECD, 2012; Olechnicka, 2012). Taking into account the current situation, where larger engagement of the academic sector in economical development (in Poland, among others) gives rise to concern, the above-mentioned model seems a more suitable solution. This is because it does not assume excessive focusing on 
economic outcomes and generating labour market needs. Moreover, it does not exclude open, pro-innovative and entrepreneurial nature of a higher education facility.

An entrepreneurial university - considered an important component of a local innovative environment - is characterized by modern management, economic-friendly structure, pro-innovative initiatives and enthusiasm towards finding new sources of financing its activity. This entrepreneurship refers also to university communities (academic personnel and students) that should be open to collaborate with local businesses and seek to apply and commercialize their knowledge and skills (Matusiak, 2006; Matusiak 2010). An entrepreneurial university builds and develops its relations with external environments - and this area of its activity is being referred to in this paper. This elaboration also attempts to (1) characterize examples of activities that strengthen university-employer relations and (2) outline the opportunities for the development of entrepreneurial university potential on the example of one of its faculties, taking into account the importance of non-material innovations - an area of pedagogues' interest.

A tendency of looking for values outside the consumption area emphasizes the meaning of innovations concerning the social area - innovations that change the way of thinking, the view of the world and interpersonal relations (Duraj \& PapiernikWojdera, 2010). A definition that encompasses the wide scope of innovations has been introduced in Oslo Manual. Here, innovation is considered in terms of implementing a new or enhanced product, service, process, marketing or organization method, workplace organization or relations with the surroundings (OECD \& EC, 2005). This knowledge is relevant, as we usually associate innovations with the implementation of new products or production methods, often forgetting about organizational innovations that may be of humanists' interest (Kulpa-Puczyńska, 2013). There are still many scientists, including those that have just started their careers, who are not sufficiently familiar with commercialization principles and possibilities of obtaining (not only financial) support to realize their projects.

The Polish Law on Higher Education, Article 4, Section 4 (2005) states that: "higher education institutions shall co-operate with the socio-economic environment, in particular by conducting research and development for business entities, [...] as well as through the involvement of employers' representatives in the development of study programmes and teaching processes" (p. 7). According to the act, the senates of higher education institutions are obliged to prepare and adopt statutes of intellectual property protection and rules for commercialization of scientific research results. The last amendment to the act allows for studying in the dual system - supported by employers who will be able offer apprenticeships and internships more easily - and people with practical experience will be able to conduct classes at higher education facilities. The above-mentioned changes in the law are intended to reinforce the cooperation of universities with labour market environment (MNiSW, 2014).

\section{Material and Methods}

A starting point for the analyses described in the next chapter is the claim that we today we are facing an expanded scope of traditional functions that have been assigned to a higher education institutions. Thus, one of the attributes of a modern university is the diversification of its goals (Drucker \& Goldstein, 2007). In Misja $i$ Strategia Uniwersytetu Kardynała Stefana Wyszyńskiego (UKSW) w Warszawie na 
lata 2014-2020, in the chapter titled "Współpraca z biznesem, otoczeniem społecznym i instytucjonalnym" (Cooperation with business, social and institutional environment) we read, among others, that: "the development of relations with the economic environment aims to create and commercialize innovations, shape education programmes with regard to employers' needs and promote creativity and entrepreneurship among students” (p. 34). When attempting to analyse selected aspects of the problem of academic entrepreneurship, including the the aspect of cooperation with employers, the author has based the provided content on the experience of the above-mentioned Institution.

References to subject literature have been made, using, among others, reports from the research on education-business relations and documents referring to tasks of a higher education institution in terms of its cooperation with the external environment. The author has also reviewed the recommendations contained in Raport $\mathrm{z}$ samooceny wydziatów UKSW and other elaborations associated with the realization of the project titled "Kwalifikacja jakości w Uniwersytecie", including the material prepared by one of the coordinators. The content of this elaboration is based on author's experience in knowledge commercialization, who has also been working as an Employer Relations Department Coordinator and who in her work follows the view of F. Trias de Bes and P. Kotler (2013) that only in organizations of creative culture "[...] ideas are born everywhere, in every department and at all levels of responsibility”(p. 252).

\section{Model of Cooperation with Employers - Results and Discussion}

The activity of the selected Institution matches the presumption that good infrastructure - i.e. libraries, laboratories, workrooms - translates into an atmosphere that favours creativity, sharing various ideas and setting up new ways of conduct (Drozdowski \& Zakrzewska et al., 2010). In case of the Cardinal Stefan Wyszyński University in Warsaw we speak about the following facilities: The Center for Training and Vocational Guidance, the state-of-the-art Center for Interdisciplinary Research and Education and the Open University (including the Academy of Entrepreneurship and the Academy of Career and Development), which helps gain and deepen the knowledge in many various scientific fields. Moreover, the university makes efforts to improve the information flow between the academic community and the external environment. One example is the Model of Cooperation with Employers, introduced on 31 October 2014 as part of the project titled "Kwalifikacja jakości w Uniwersytecie", co-financed by the European Social Fund of the European Union.

The described model is intended to serve as an element of the internal system of quality assurance in education and the contained therein procedures are expected to improve the coordination between Department Committees and other University units that are involved in building relations with the social and economic environment. The tool's priority goal is to facilitate the cooperation between the Institution and employers in terms of: development of education results' projects and projects of educational programmes; specification of a graduate's profile and education paths; conducting scientific research and organization of professional trainings and apprenticeships. The model covers procedures associated with ordering specific postgraduate studies, seminaries, expertises by external stakeholders, as well as procedures concerning the cooperation with employers in the field of publishing scientific elaborations or organization of conferences. 
The implementation of this model entails the need of appointing Department Business Councils and incorporating them into the structure of employers' delegates representing a department-specific business sector, as well as Employer Relations Department Coordinators, whose competencies include:

- coordinating actions related to the analysed area - by making use of, among others, a virtual platform for cooperation with employers;

- updating the faculty business offer, together with the Departmental Didactics Committee and the Dean's Representative for promoting the faculty business offer;

- creating databases of employers who offer apprenticeships and databases of academic teachers with practical experience;

- preparing a tool for educational results' draft evaluation or a form for educational programme draft evaluation.

It is noteworthy that in the framework of the foregoing cooperation (up to November 2014) with the previous department coordinators the following projects were realized: departmental databases of employers, leaflets addressed to employers that included profiles of graduates of all study courses, study visits at employers' facilities for all study courses aimed at consulting education programmes. Departmental Business Councils can make proposals for adapting educational offer to current needs of the labour market, indicate educational areas that should make use of practical training and recommend solutions aimed at commercialization of scientific research results. The rules regarding the appointment and specific tasks of Departmental Business Councils and coordinators are contained in the Disposition of the Rector of the UKSW, which has introduced the discussed model (No. 68/2014).

In conjunction with the presented Model of Cooperation with Employers and relevant objectives set out in Misja $i$ Strategia Wydziatu Nauk Pedagogicznych (WNP) there are additional actions held regarding the development of departmental entrepreneurship, including the enhancement of cooperation with external stakeholders. The initiatives, presented in Chart 1 , have been scheduled for realization within the period of the forthcoming two years and include, among others, the results of survey research contained in the report titled Studenci o funkcjonowaniu swojej uczelni, elaborated by the Center for Research and Evaluation of Education Quality at UKSW. They also refer to the need of students being submitted during didactic classes (e.g. at the request of organizing additional meetings with labour market experts) and to the information available in SWOT Analysis of Faculty of Pedagogical Sciences where the need of broadening the cooperation by local associations and employer groups has been underscored. The actions listed in the chart do not constitute a closed list of planned forms of activity.

Chart 1. Faculty Initiatives that support academic entrepreneurship, including the cooperation with external stakeholders

\begin{tabular}{|l|l|}
\hline \multicolumn{1}{|c|}{$\begin{array}{c}\text { Selected operational objectives resulting } \\
\text { from Misja i Strategia WNP UKSW } \\
\text { (2014-2020) }\end{array}$} & $\begin{array}{c}\text { Activities that reinforce the cooperation with } \\
\text { external stakeholders - examples }\end{array}$ \\
\hline $\begin{array}{l}\text { IN TERMS OF THE QUALITY OF } \\
\text { EDUCATION AND THE DEVELOPMENT }\end{array}$ & $\begin{array}{l}\text { The work on enriching the didactic offer with } \\
\text { entrepreneurship workshops that shall prepare } \\
\text { students to effective functioning on the labour } \\
\text { market, including self-employment; recruiting } \\
\text { (aside from the WNP workers with practical }\end{array}$ \\
\hline - Adjusting the didactic offer to current
\end{tabular}




\begin{tabular}{|l|l|}
\hline labour market requirements & $\begin{array}{l}\text { experience) external experts specializing in the } \\
\text { above-mentioned field (including self-employed } \\
\text { graduates); } \\
\text { Organization of a methodical seminary, } \\
\text { focusing on the practical experience among the } \\
\text { WNP students (with the participation of } \\
\text { students, Deanery Authorities, apprenticeship } \\
\text { coordinators, Career Offices and local } \\
\text { employers); taking care of the cyclical and } \\
\text { pragmatic nature of the above-mentioned } \\
\text { project. }\end{array}$ \\
\hline $\begin{array}{l}\text { IN TERMS OF THE COOPERATION } \\
\text { INSTITUTIONAL ENVIRONMENTS }\end{array}$ & $\begin{array}{l}\text { Inviting practical specialists within the } \\
\text { framework of regular open lectures (combined } \\
\text { with a discussion) in order to improve the match } \\
\text { of the WNP students' competencies to social and } \\
\text { economic needs; the lectures are also intended to } \\
\text { support cooperation with graduates who are } \\
\text { environment, particularly including employer } \\
\text { associations, in order to determine the } \\
\text { demand for specific skills and competencies } \\
\text { and/or speakers. } \\
\text { The work on creating the Departmental Center } \\
\text { of Educational Initiatives, intended for } \\
\text { becoming a cooperation platform between the } \\
\text { university and social-life institutions - a } \\
\text { platform constituting a tool for encouraging the } \\
\text { WNP students and graduates to be active, a } \\
\text { place for gaining their first professional } \\
\text { experience and realizing their own projects. }\end{array}$ \\
\hline
\end{tabular}

*WNP - Faculty of Pedagogical Sciences

(Source: own elaboration)

The scope of activities that facilitate the development of academic entrepreneurship includes students' involvement in the realization of departmental projects, which can help them develop skills valued today (organization of work, effective communication skills). This sort of initiatives gives access to wide research material and unexplored practical solutions. Another important things is the support that is being offered to students in terms of their integration to the labour market, through e.g. sharing information about recruitment opportunities at institutions and companies cooperating with the WNP. Here, it is noteworthy that the department relies, first of all, on the cooperation with employers who can offer workplaces for graduates and who have been using modern methods and technologies in relation to didactic processes. On the other hand, the general activities undertaken by universities, relevant for the content of this elaboration, include encouraging the UKSW students and graduates to establish their own businesses and supporting their activity, as well as providing academic teachers with suitable skills and competencies concerning the process of commercialization of scientific research results. More information on this matter can be found, among others, in Misja $i$ Strategia Uniwersytetu Kardynata Stefana Wyszyńskiego w Warszawie na lata 2014-2020.

The knowledge, relevant in terms of the developed activities, comes from internal academic sources and is rooted in the concluded and planned contracts with: companies, employer associations, business-related institutions, training companies, labour market institutions, local governments, non-profit organizations, schools and $\mathrm{R} \& \mathrm{D}$ centers. It should be noted that the Polish system of business-related institutions 
includes: entrepreneurship centers, e.g. business incubators, business centers; innovation centers, including science parks, knowledge and technology transfer centers and financial institutions as e.g. local loan funds, business angel networks. The above-mentioned institutions constitute a diversified group of non-commercial establishments. When writing about the cooperation with employers it is worth mentioning - referring to the results of the study titled Universum Student Survey 2012. University Report - Polish Edition - Cardinal Stefan Wyszyński University in Warsaw (Humanities/Liberal Arts/Education) - that students are interested in being employed particularly in the following branches: Media and Advertisement, Educational and Research Institutions, Public Sector and Governmental Agencies. This, however, leads to raising the following questions: Should higher education institutions fulfil students' expectations and cooperate mainly with employers representing the above-mentioned branches? Will this sort of professional preparation be effective? Students also prefer to work in small and medium-size companies and their career objective is to achieve safe and stable employment.

\section{Conclusions}

The presented herein Model of Cooperation with Employers is intended to make it easier for the representatives of the business world to access academic databases and results of the research conducted by universities. It consists in preparing a comprehensive offer of cooperation with employers and cooperation of all UKSW departments in this field. It is necessary to point out that the sustainability of advantages associated with implementing this model will in the longer term depend on University's interest in following the path of entrepreneurship and innovativeness and offering appropriate support. It seems certain - especially in the context of a developing economy based on knowledge and challenges of a flexible labour market. However, it is necessary to secure internal coordination of the project and initiate further activities, as described in, among others, Misja i Strategia UKSW and strategies of its departments.

According to also the author, the development of the entrepreneurial potential of higher education facilities (the humanistic ones too) can include also other initiatives than the previously mentioned ones, i.e.: reinforcing the activity of academic interdisciplinary research teams which include students; organizing apprenticeships in innovative companies; employers' initiatives concerning the organization of additional professional trainings and consultations; establishing partnerships between employers and particular departments (e.g. WNP) - as an important intermediary in the process of transferring knowledge to economy and as a source of ideas; cooperation between particular departments in favour of academic entrepreneurship; promoting cooperative activities (good practices) through, among others, conferences and publications.

There are also several challenges associated with the above-mentioned activities, which include: reluctance of a part of the academic community to the process of commercialization and striving towards cooperation with business entities, which can result from the need of focusing on other activities, as scientific development or publishing; insufficient competencies of research and didactic personnel for developing and offer of cooperation with external establishments; limited capabilities of many higher education institutions regarding their financial contribution to the realization of projects; limited scope of international cooperation regarding conducting research, which is indispensable in the context of global competitiveness. 
Barriers can also be found on the companies' side or result from external factors. This topic, however, due to its complexity, constitutes material for a separate elaboration.

More information about the condition and capabilities of cooperation between Polish higher education institutions and local environments can be found, among others, in the following publications: Polskie szkolnictwo wyższe - stan, uwarunkowania i perspektywy, a report compiled as a part of an environmental project titled "Strategia rozwoju szkolnictwa wyższego 2010-2020", conducted by, among others, the Polish Rectors Foundation; Diagnoza stanu szkolnictwa wyższego w Polsce by Ernst\&Young and the Institute for Market Economics as a part of the preparation of "Strategia rozwoju szkolnictwa wyższego w Polsce do 2020 roku" and Biznes dla edukacji. Raport specjalny dotyczacy wspólpracy biznesu i edukacji $w$ Polsce, developed as a part of a project realized by the Polish Agency for Enterprise Development in cooperation with the Polish Human Resources Management Association.

\section{References}

Act of 27 July 2005 Law on Higher Education (Official Journal of Laws of 2005, No. 164, item 1365, as amended). Retrieved January 15, 2015, from http://www.nauka.gov.pl/g2/oryginal/2013_12/d687905792f5ff6a3ecf84d7df4f8e 57.pdf

Cardinal Stefan Wyszyński University (UKSW) in Warsaw. (2014). Misja i Strategia Uniwersytetu Kardynała Stefana Wyszyńskiego w Warszawie na lata 2014 2020. Retrieved January 15, 2015, from http://ksztalcenie.uksw.edu.pl/content/misja-i-strategia-uksw

Drozdowski R., Zakrzewska A., Puchalska K., Morchat M., \& Mroczkowska D. (2010). Wspieranie postaw proinnowacyjnych przez wzmacnianie kreatywności jednostki. Warszawa: Polish Agency for Enterprise Development. Retrieved January 15, 2015, from http://www.e-msp.pl/files/74/81/380/9721.pdf

Drucker J. \& Goldstein H. (2007). Assessing the regional economic development impacts of universities: a review of current approaches. International Regional Science Review, 30 (1), 20-46.

Duraj J., \& Papiernik - Wojdera M. (2010). Przedsiębiorczość i innowacyjność. Warszawa: Wydawnictwo Difin.

Goldstein H. A. (2010). The'entrepreneurial turn' and regional economic development mission of universities. Annals of Regional Science, 44 (1), 83-109.

Gunasekara, C. (2006). The generative and developmental roles of universities in regional innovation systems. Science and Public Policy, 33 (2), 137-150.

Kulpa-Puczyńska A. (2013). Szkoła wyższa jako instytucja wspierająca działalność innowacyjną przedsiębiorstw. Wybrane problemy. Problemy Profesjologii, 1, 89100.

Leydesdorff L. \& Etzkowitz H. (1998). The Triple Helix as a model for innovation studies. Science and Public Policy 25 (3), 195-203.

Matusiak K. B. (2006). Rozwój systemów wsparcia przedsiębiorczości. Radom Łódź: ITE-PIB The Institute for Sustainable Technologies - National Research Institute. 
Matusiak K. B. (2010). Budowa powiązań nauki z biznesem w gospodarce opartej na wiedzy. Rola i miejsce uniwersytetu w procesach innowacyjnych. Warszawa: SGH Warsaw School of Economics.

Ministry of Science and Higher Education (MNiSW). (2014). Nowelizacja ustawy o szkolnictwie wyższym opublikowana w Dzienniku Ustaw. Retrieved January 15, 2015, from http://www.nauka.gov.pl/aktualnosci-ministerstwo/nowelizacjaustawy-o-szkolnictwie-wyzszym-opublikowana-w-dzienniku-ustaw.html

OECD \& European Commission (2012). A Guiding Framework for Entrepreneurial Universities, Final version 18th. Retrieved April 15, 2015, from http://www.oecd.org/site/cfecpr/EC-

OECDEntrepreneurialUniversitiesFramework.pdf

OECD \& European Commission (2005). Oslo Manual. Guidelines for Collecting and Interpreting Innovation Data (3rd ed.). Paris.

Olechnicka A. (2012). Potencjał nauki a innowacyjność regionów. Warszawa: Wydawnictwo Naukowe Scholar.

Trías de Bes F., \& Kotler P. (2013) Innowacyjność. Przepis na sukces. Model „od A do F” (M. Zawiślak \& J. Środa, Trans.). Poznań: REBIS Publishing Hause Ltd. (Original work published 2011). 